\title{
Effects of the percentage of concentrate on rumen fermentation, nutrient digestibility, plasma metabolites, and milk composition in mid-lactation goats
}

\author{
A. Serment, ${ }^{*}{ }^{1}$ P. Schmidely, ${ }^{*} \dagger$ S. Giger-Reverdin, ${ }^{*} \dagger$ P. Chapoutot, ${ }^{*} \dagger$ and D. Sauvant ${ }^{*} \dagger$ \\ ${ }^{*}$ AgroParisTech, UMR791 Modélisation Systémique Appliquée aux Ruminants, and \\ †INRA, UMR791 Modélisation Systémique Appliquée aux Ruminants, 16 rue Claude Bernard, F-75005 Paris, France
}

\begin{abstract}
The aim of this work was to study the effects of the dietary percentage of concentrate on patterns of intake, the evolution of rumen fermentation characteristics and plasma metabolites after a meal, nutrient digestibility, and milk production and composition in a medium-term trial in dairy goats. These effects have been well studied in dairy cattle but seldom in goats. Thirteen ruminally and duodenally cannulated dairy goats (95 $\pm 4 \mathrm{~d}$ in milk) fed ad libitum were used in this study. Goats were assigned to 1 of 2 dietary treatments: high-concentrate $(70 \%$ concentrate on dry matter basis) or a low-concentrate (35\%) total mixed rations. The experiment was conducted over a period of $10 \mathrm{wk}$, including $3 \mathrm{wk}$ of adaption to the diets. Patterns of intake, rumen fermentation characteristics, and plasma metabolites after a meal and fatty acids profile of milk fat were compared at the onset and at the end of the experiment. The increase in dietary percentage of concentrate decreased rumen $\mathrm{pH}$, acetate to propionate ratio, ammonia- $\mathrm{N}$ concentration, and plasma urea concentration. The percentage of concentrate did not affect total volatile fatty acid concentrations. The high-concentrate diet increased the rate of intake during the morning meal at the onset of the experiment, whereas it decreased total dry matter intake and the rate of intake during the morning meal at the end of the experiment. The high-concentrate diet resulted in greater organic matter digestibility. Raw milk yield and protein yield were greater in goats fed the highconcentrate diet, whereas fat yield was not affected by dietary treatments. The milk fat content was lower in goats fed the high-concentrate diet. Proportions of the trans-C18:1 isomer relative to total fatty acids in milk were higher with the high-concentrate diet, but no modification of the proportion of total trans-C18:1 was detected, in particular no shift from trans-11 C18:1 to trans-10 C18:1 was observed. Further, the isomer
\end{abstract}

Received November 26, 2010.

Accepted April 4, 2011.

${ }^{1}$ Corresponding author: amelie.serment@agroparistech.fr trans-10,cis-12 C18:2 was not detected. Data from this study could be used for a new modeling approach or to improve existing models.

Key words: dairy goat, percentage of concentrate, rumen, milk composition

\section{INTRODUCTION}

European consumption of goat milk products has increased for more than $20 \mathrm{yr}$, and farmers have responded by increasing goat milk production (FAO, 2010). An increase in milk production is generally achieved by the use of high-concentrate diets (Morand-Fehr et al., 2007) at the expense of milk fat content (MFC) and sometimes with higher milk protein content (MPC; Schmidely and Sauvant, 2001; Chilliard and Ferlay, 2004). With high-concentrate diets, the proportions of fatty acids (FA) in MFC are generally altered toward a decrease in short- and medium-chain FA (C12 to C16) and an increase in proportions of total trans C18:1 isomers (Calderon et al., 1984; Ledoux et al., 2002; Andrade and Schmidely, 2006).

Feeding behavior can be modified by feeding highconcentrate diets (Abijaoudé et al., 2000b; Desnoyers et al., 2008a). Goats fed a diet with 60 compared $30 \%$ concentrates spent less time eating and ruminating and more time resting during the hours following the meal distribution (Desnoyers et al., 2008a). Moreover, goats fed high-concentrate diets had lower digestibility of dietary fiber (Kawas et al., 1991), as was also observed in bovine species (see reviews of Huhtanen et al., 2009; Nousiainen et al., 2009). This is associated with changes in the ruminal microbial ecosystem because of a decrease in rumen $\mathrm{pH}$ when the percentage of concentrate increases (Archimède et al., 1996).

Unlike the situation in dairy cows (Khorasani and Kennelly, 2001; Lechartier and Peyraud, 2010), few studies have been conducted in which the effects of a high-concentrate diet on intake behavior, fermentation characteristics in the rumen, and milk yield and composition were measured simultaneously, at different time scales (either after feeding or over several weeks; Kawas et al., 1991; Santini et al., 1992). The objectives 
of this study were to determine the effects of the dietary percentage of concentrate on (1) intake behavior, ruminal measurements, and plasma metabolites after feeding; (2) in sacco and in vivo digestibility of the dietary constituents; and (3) milk production and milk composition during a 10 -wk trial.

\section{MATERIALS AND METHODS}

\section{Animals, Design, Diets, and Feeding}

Goats were cared for and handled in accordance with the French legislation on animal experimentation in line with the European Convention for the Protection of Vertebrates used for Experimental and other Scientific Purposes (European Directive 86/609). Thirteen ruminally and duodenally cannulated Saanen or Alpine goats $(\mathrm{BW}=62 \pm 4 \mathrm{~kg}$; parity $=3 \pm 1$ lactation) were used in a 10 -wk trial, starting 10 wk after surgical cannulation. At the onset of the trial, goats were $95 \pm 4$ DIM, with $3.3 \pm 0.38 \mathrm{~kg} / \mathrm{d}$ of raw milk yield (RMY), an MFC of $38.0 \pm 5.11 \mathrm{~g} / \mathrm{kg}$, and an MPC of $32.7 \pm 2.46 \mathrm{~g} / \mathrm{kg}$. Goats were housed in individual pens throughout the trial, except for 3 wk when they were housed in individual metabolism crates for determination of diet digestibility.

At the onset of the trial (wk 1), goats were fed a basal TMR containing $52.5 \%$ concentrate for $1 \mathrm{wk}$. At the end of this first week, goats were randomly assigned to 1 of 2 experimental groups, according to their parity, their RMY during this week, and their MFC and MPC. Goats were then progressively switched from the basal TMR to their experimental TMR over wk 2 by increasing or decreasing by $5 \%$ the proportion of the concentrate in the TMR every $2 \mathrm{~d}$ until the concentrate proportions of the experimental diets were achieved. The experimental TMR (Table 1) contained either a high percentage of concentrate $(\mathbf{H}, 70 \%$ concentrate/ DM, 6 goats) or a low percentage of concentrate $(\mathbf{L}$, $35 \%$ concentrate/DM, 7 goats). Goats were fed ad libitum (approximately 10\% of refusals) for $8 \mathrm{wk}$. Feed was offered individually twice a day at 0800 and 1600 $\mathrm{h}$, after milking, with two-thirds allocated in the afternoon and one-third in the morning, according to the time interval between milkings. Energy $\left(\mathrm{NE}_{\mathrm{L}}\right)$ and nitrogen (digestible protein in the intestine, PDI) values of the feed and TMR were calculated according to the additive method from INRA tables (Baumont et al., 2007 ). The forage was a mixture of grass hay $(46 \%$ of forage DM) and dehydrated alfalfa (Rumiluz, Désialis, Paris, France; $54 \%$ of forage DM). The concentrate was composed of a commercial concentrate (Agralys Aliment, Châteaudun, France) and sugar beet pulp silage. Soybean meal and calcium palm oil salt were added to the concentrate part of the $\mathrm{L}$ diet and basal diet so that the 3 TMR had similar calculated $\mathrm{CP}$ and total FA contents, respectively. Feed offered and refusals were individually weighed daily. Distributed feed and refusals samples were taken at wk 1 for the basal diet and at wk 4, 6, and 10 for the experimental TMR. Samples of feed were oven-dried at $87^{\circ} \mathrm{C}$ for $24 \mathrm{~h}$ and ground through a 1-mm sieve before being analyzed.

\section{Animal Performance}

Goats were weighed weekly in the middle of the day $(1400 \mathrm{~h})$. They were milked twice a day, at 0700 and $1530 \mathrm{~h}$. Milk samples were taken weekly from 2 consecutive milkings and stored at $4^{\circ} \mathrm{C}$ with bronopol (Trillard, Surgères, France) until analysis of fat, protein, and lactose contents. Milk samples were also taken at wk 1,6 , and 10 and were frozen without preservative at $-20^{\circ} \mathrm{C}$ for analysis of milk FA profile.

From the onset of the trial, blood samples were taken weekly, before the morning feeding, in heparinized tubes from the jugular vein. They were immediately centrifuged, and plasma was stored at $-20^{\circ} \mathrm{C}$ until analysis of glucose, NEFA, urea, BHBA, insulin, L-lactate, and osmotic pressure. A supplementary blood sample was collected for immediate analysis of blood $\mathrm{pH}$ and blood bicarbonate concentration (SAS ABL77, Radiometer Analytical, Neuilly-Plaisance, France).

\section{Patterns of DMI, Ruminal Fermentation, and Plasma Concentrations After Feeding}

At wk 1, 4, and 10, the dynamic patterns of intake were recorded by weighing devices placed under the feed trough, which recorded the weight of feed in the trough every 2 min (Desnoyers et al., 2008a). The recordings were made for each goat during 4 successive morning meals of each week.

At wk 4 and 10, $50 \mathrm{~mL}$ of rumen contents was individually collected at $0,1,2,4$, and $6 \mathrm{~h}$ after the morning feeding on the fourth day of intake recording. Rumen $\mathrm{pH}$ and redox potential (equilibrium value after $30 \mathrm{~min}$ ) were measured and 4 aliquots were taken at each time. Filtered rumen fluid $(3 \mathrm{~mL})$ was acidified with $25 \% \mathrm{H}_{3} \mathrm{PO}_{4}(\mathrm{vol} / \mathrm{vol})$ and stored at $-20^{\circ} \mathrm{C}$ until analysis of VFA. A second aliquot of rumen fluid $(6 \mathrm{~mL})$ was mixed with $12.5 \% \mathrm{TCA}$ (vol/vol) and kept at $-20^{\circ} \mathrm{C}$ until analysis of ammonia- $\mathrm{N}\left(\mathrm{NH}_{3}-\mathrm{N}\right)$. A third aliquot of rumen fluid $(3 \mathrm{~mL})$ was mixed with $0.15 \%$ $\mathrm{HCl}(\mathrm{vol} / \mathrm{vol})$ and stored at $-20^{\circ} \mathrm{C}$ for analysis of soluble carbohydrate. The fourth aliquot was stored without preservative at $-20^{\circ} \mathrm{C}$ for analysis of osmotic pressure.

Ten milliliters of blood was individually collected from the jugular vein in heparinized tubes on the same 
Table 1. Ingredient composition, chemical composition, and nutritive values of low- $(\mathrm{L})$ and high- $(\mathrm{H})$ concentrate diets

\begin{tabular}{|c|c|c|c|c|}
\hline \multirow[b]{2}{*}{ Item } & \multicolumn{2}{|c|}{ Diet } & \multirow[b]{2}{*}{ SEM } & \multirow{2}{*}{$\frac{P \text {-value }}{\text { Concentrate }^{1}}$} \\
\hline & $\mathrm{L}$ & $\mathrm{H}$ & & \\
\hline \multicolumn{5}{|l|}{ Ingredients $(\mathrm{g} / 100 \mathrm{~g}$ of $\mathrm{DM})$} \\
\hline Forage & 65 & 30 & & \\
\hline Grass hay & 29.9 & 13.8 & & \\
\hline Dehydrated alfalfa & 35.1 & 16.2 & & \\
\hline Concentrate & 35 & 70 & & \\
\hline Commercial concentrate $^{2}$ & 20 & 50 & & \\
\hline Sugar beet pulp silage & 7 & 20 & & \\
\hline Calcium palm oil salt & 1.4 & - & & \\
\hline Soybean meal & 6.6 & - & & \\
\hline \multicolumn{5}{|l|}{ Chemical composition $^{3}$ (g/100 g of DM) } \\
\hline $\mathrm{CP}$ & 16.7 & 17.7 & 0.37 & 0.18 \\
\hline $\mathrm{NDF}$ & 40.9 & 36.0 & 1.47 & 0.04 \\
\hline $\mathrm{ADF}$ & 24.4 & 20.1 & 0.97 & 0.01 \\
\hline Acid detergent lignin & 3.89 & 2.97 & 0.303 & 0.06 \\
\hline Starch & 4.38 & 9.70 & - & - \\
\hline Ash & 8.47 & 8.37 & 0.202 & 0.72 \\
\hline Fatty acid (FA) & 2.33 & 2.81 & 0.750 & 0.04 \\
\hline \multicolumn{5}{|l|}{ Total FA (g/100 g of FA) } \\
\hline $\mathrm{C}_{12: 0}-\mathrm{C}_{15: 0}$ & 1.89 & 0.78 & 0.078 & 0.01 \\
\hline $\mathrm{C}_{16: 0}^{12.0}$ & 37.3 & 16.41 & 0.070 & $<0.001$ \\
\hline $\mathrm{C}_{18: 0}$ & 4.5 & 3.41 & 0.029 & 0.001 \\
\hline cis-9 $\mathrm{C}_{18: 1}$ & 23.5 & 29.2 & 0.17 & 0.002 \\
\hline cis- $9,12 \mathrm{C}_{18: 2}$ & 17.3 & 33.1 & 0.05 & $<0.001$ \\
\hline cis- $9,12,15 \mathrm{C}_{18: 3}$ & 9.2 & 10.4 & 0.05 & 0.003 \\
\hline $\mathrm{C}_{20: 0}-\mathrm{C}_{24: 0}$ & 1.47 & 1.45 & 0.031 & 0.70 \\
\hline \multicolumn{5}{|l|}{ Nutritive value } \\
\hline Electrolytic balance $(\mathrm{mEq} / \mathrm{kg}$ of $\mathrm{DM})$ & 500 & 419 & & \\
\hline Net energy $^{4}(\mathrm{MJ} / \mathrm{kg}$ of DM) & 5.88 & 6.75 & & \\
\hline $\mathrm{PDIN}^{4,5}(\mathrm{~g} / \mathrm{kg}$ of $\mathrm{DM})$ & 113 & 114 & & \\
\hline $\mathrm{PDIE}^{4,5}(\mathrm{~g} / \mathrm{kg}$ of DM$)$ & 104 & 114 & & \\
\hline
\end{tabular}

${ }^{1}$ Effect of the percentage of concentrate.

${ }^{2} 18 \%$ maize, $14 \%$ sugar beet pulp, $12 \%$ sunflower meal, $10 \%$ wheat, $10 \%$ soybean, $9 \%$ rapeseed meal, $6 \%$ soybean meal, $4 \%$ wheat distiller, $3.5 \%$ linseed, $3 \%$ pea seed, $1 \%$ rapeseed oil, $3 \%$ molasses, $6.5 \%$ mineral and vitamin premix.

${ }^{3} \mathrm{n}=7$ for analysis of NDF, ADF, acid detergent lignin, ash contents; $\mathrm{n}=2$ for $\mathrm{CP}$ and $\mathrm{FA}$ contents; $\mathrm{n}=1$ for starch content.

${ }^{4}$ Calculated according to the additive method from INRA tables (Baumont et al., 2007).

${ }^{5} \mathrm{PDIN}$ (or $\mathrm{E}$ ) = protein digestible at the level of intestine when nitrogen (or energy) is limiting for microbial protein synthesis.

days as samplings of rumen contents, at $0,0.5,1,1.5$, $2,3,4$, and $6 \mathrm{~h}$ after the morning meal. Samples were immediately centrifuged for $10 \mathrm{~min}$ at $3,000 \times \mathrm{g}$ at a temperature of $5^{\circ} \mathrm{C}$, and plasma was stored at $-20^{\circ} \mathrm{C}$ until analysis of glucose, NEFA, urea, BHBA, insulin, L-lactate, and osmotic pressure.

\section{In Situ Ruminal Degradability of Substrate}

In wk 9, ruminal degradability of DM, NDF, ADF, and starch in 12 goats (6 for each group) was determined by using the nylon bag procedure derived from Vérité et al. (1987). Two ingredients were incubated: grass hay of the diets (to measure the DM, NDF, and $\mathrm{ADF}$ degradability) and maize grain (to measure $\mathrm{DM}$ and starch degradability). Samples of ingredients were ground through a 1-mm screen. Nylon bags $(44-\mu \mathrm{m}$ pore size, $6 \mathrm{~cm} \times 15 \mathrm{~cm}$, SaatiTech, Appiano Gentile, Italy) containing $3 \mathrm{~g}$ of ingredient were incubated in triplicate (1 d for each replicate) for $4,8,16,24$, and $48 \mathrm{~h}$ for grass hay and for $2,4,8,16$, and $24 \mathrm{~h}$ for maize. When removed from the rumen, bags were rinsed in cold water and washed for $10 \mathrm{~min}$ in cold water to remove rumen particles and rumen microbes attached to substrates. Bags were then frozen to stop fermentation. After freezing, they were dried in an air-oven at $60^{\circ} \mathrm{C}$ for $48 \mathrm{~h}$, and then analyzed for DM. Residues from bags were pooled within each goat for the incubation duration and then analyzed for NDF and ADF (grass hay) and starch (maize). 


\section{Whole-Tract Digestibility}

To measure the apparent fecal digestibility of diets (6 goats per diet), feed offered, refusals, and total feces were weighed daily during 5 consecutive days in wk 6 . Aliquots of refusals and feces were collected daily at the same time, pooled by animal at the end of the 5 $\mathrm{d}$, dried in an air-oven at $87^{\circ} \mathrm{C}$ for $24 \mathrm{~h}$, and ground through a $1-\mathrm{mm}$ sieve before analyses of DM, NDF, $\mathrm{ADF}$, and starch.

\section{Analytical Procedures}

The DM contents of TMR, refusals, feces, and nylon bag residues were determined by oven-drying at $103^{\circ} \mathrm{C}$ for $24 \mathrm{~h}$. The NDF content was estimated by the method of Van Soest and Wine (1967) modified by Giger et al. (1987) with the use of a heat stable $\alpha$-amylase but without sodium sulfite and decalin. The contents of $\mathrm{ADF}$ and acid detergent lignin were obtained using a sequential approach on the NDF residue (Giger et al., 1987). Ash and starch contents were analyzed according to ISO (1978) and AFNOR (1997) methods, respectively. Total $\mathrm{N}$ was determined by the Dumas technique (Sweeney and Rexroad, 1987).

Concentrations of $\mathrm{NH}_{3}-\mathrm{N}$ and soluble carbohydrate of rumen fluid were analyzed with an autoanalyzer (Technicon, Oise, France), according to the methods of Weatherburn (1967) and Brown and Boston (1961), respectively. Concentrations of VFA were determined by gas chromatography (Kristensen, 2000). Osmotic pressures of rumen fluid and plasma were determined using an osmometer (Mark3, Fiske, Radiometer Analytical). Plasma samples were analyzed using a Cobas Mira-analyzer (Roche, Mannheim, Germany) with commercial kits for glucose (Gluco-quant, Glucose/HK, Roche), NEFA [NEFA-HR(2), Wako Chemical GmBH, Neuss, Germany], urea (Urea/BUN, Roche) and L-lactate (Lactate, Roche). The BHBA concentrations were analyzed by the procedure of Barnouin et al. (1986). Insulin was analyzed using ELISA kits (Mercodia Ovine Insulin ELISA, Uppsala, Sweden).

Fat and protein contents of milk were analyzed by infrared spectrophotometry (Syndicat Interdépartemental de l'Elevage, Le Mée, France). Analysis of milk and diet FA contents and profiles was described by Andrade and Schmidely (2006).

\section{Calculations and Statistical Analysis}

The rate of feed intake and the cumulated DMI after each feeding, expressed in grams per kilogram of BW were calculated from the recordings of the weight of feed in the trough every 2 min (Desnoyers et al., 2008a).
The following nonlinear model (Baumont, 1988) was then applied to each profile (for each goat and each recording day) using the NLIN procedure of SAS (SAS Institute, 2000):

$$
\text { Cumulative DMI }(\mathrm{t})=A\left(1-\mathrm{e}^{-B t}\right) \text {, }
$$

where $A$ is the asymptote, $A \times B$ the slope of the curve, and $t$ the time after feeding.

For each period and goat, $\mathrm{pH}$ data were described by a third-degree polynomial model as described by Dragomir et al. (2008). The minimal pH, initial pH, the amplitude of the $\mathrm{pH}$ decrease (initial $\mathrm{pH}$ - minimal $\mathrm{pH}$ ), and the time when the rumen $\mathrm{pH}$ was below 6.0 were calculated. Daily DMI and RMY were averaged by goat and by week.

The fitted parameters of the DMI patterns, the parameters on $\mathrm{pH}$ profiles after feeding, ruminal and plasma data, and weekly performance data were analyzed using the mixed procedure of SAS (SAS Institute, 2000) for repeated measurements. The model included fixed effects of the percentage of the concentrate, the week, the interaction between the percentage of concentrate and the week, and an appropriate covariate (value in wk 1). Animal was considered as a random effect. For ruminal and plasma data, the fixed effects of the time after feeding and its interaction with the percentage of concentrate were included in the model. The repeated measurements were applied to the time after feeding and not to the week, and no covariate was used. For the fitted parameters of the DMI patterns, we added a fixed effect of recording day. The models were tested with 4 covariance structures: compound symmetry, heterogeneous compound symmetry, first-order autoregressive, and heterogeneous autoregressive (1). The covariance structure that provided the smallest Akaike's information criteria was selected.

In sacco disappearance of DM, calculated from its proportion remaining in the bag after incubation in the rumen, was determined for each nylon bag. The DM disappearance was averaged by goat and by incubation time (triplicate). In sacco degradability of NDF and $\mathrm{ADF}$ (for grass hay) and starch (for maize) were then calculated. Calculated DM, NDF, ADF, and starch disappearances were described with the nonlinear model of Ørskov and McDonald (1979):

$$
\text { Disappearance }=a+b\left(1-\mathrm{e}^{-c t}\right),
$$

where $a$ is the soluble fraction (\% of total DM, NDF, $\mathrm{ADF}$, or starch), $b$ the degradable fraction (\% of total DM, NDF, ADF, or starch), $t$ the time of rumen incubation (h), and $c$ the relative rate of degradation 
of fraction $b\left(\mathrm{~h}^{-1}\right)$. Nonlinear parameters $a, b$, and $c$ were estimated using the NLIN procedure of SAS (SAS Institute, 2000). The effective degradability of DM (EDDM), NDF (EDNDF), ADF (EDADF), and starch (EDS) were calculated as:

$$
\begin{gathered}
\text { EDDM, EDNDF, EDADF, or EDS }= \\
a+[(b \times c) /(c+k)],
\end{gathered}
$$

where $k$ is the estimated rate of outflow from the rumen, fixed at $0.06 \mathrm{~h}^{-1}$ (Vérité et al., 1987).

In sacco DM data (parameters $a, b, c$, and EDDM) were analyzed using the GLM procedure of SAS (SAS Institute, 2000) with a model including the percentage of concentrate, the fixed effect of the animal, and day. As residues from bags were pooled within each goat for analysis of NDF, ADF, or starch, NDF, ADF, and starch disappearance data were analyzed using the GLM procedure of SAS with only a test of the effect of the diet. The same model was applied to data of apparent fecal digestibility.

Milk FA proportions measured at wk 6 and 10 were averaged by goat, and preliminary statistical analysis indicated no significant effect of week on any FA proportions. Individual data of milk FA were analyzed using the GLM procedure of SAS (SAS Institute, 2000) with a model including the percentage of concentrate and the appropriate covariate obtained in wk 1. All data presented in this paper are least squares means \pm SEM.

\section{RESULTS}

\section{Chemical Composition and Nutritive Values of the Diets}

The $\mathrm{H}$ diet had lower NDF and ADF contents and higher contents of starch and FA than the L diet (Table 1). The $\mathrm{H}$ diet had lower proportions of C16:0 and C18:0 and higher proportions of cis-9 C18:1, cis9,cis-12 C18:2, and cis-9,cis-12,cis-15 C18:3 in dietary FA than the L diet.

\section{DMI}

The effects of recording day and percentage of concentrate on the parameters calculated to assess the DMI pattern after a meal were never significant. However, an interaction was found between the percentage of concentrate and the time of the asymptote of the cumulative intake profile (parameter $A: P<0.001$ ) and the rate of intake (parameter $B: P=0.01$ ). Parameters $A$ and $B$ of goats fed the $\mathrm{H}$ diet decreased, respectively, from 15.3 to $10.5 \pm 0.72 \mathrm{~g} / \mathrm{kg}$ of $\mathrm{BW}(P<0.001)$ and from 0.055 to $0.035 \pm 0.0041 / \mathrm{min}(P<0.001)$ between wk 4 and 10 , whereas these measurements did not change with time for goats fed the $\mathrm{L}$ diet $(14.5 \pm 0.72 \mathrm{~g} / \mathrm{kg}$ of BW and $0.037 \pm 0.0041 / \mathrm{min}$, respectively).

Daily DMI was not influenced by the percentage of concentrate (Table 2). However, an interaction was observed between the percentage of concentrate and time on daily DMI relative to BW (Table 2), with a higher decrease of the daily DMI relative to BW for goats fed the $\mathrm{H}$ diet than for goats fed the $\mathrm{L}$ diet between wk 4 and 10 (Figure 1a).

\section{Rumen Fermentation Characteristics After Feeding}

Rumen $\mathrm{pH}$ and $\mathrm{NH}_{3}-\mathrm{N}$ concentration were lower and the rumen redox potential and soluble carbohydrate concentration were higher for goats fed the $\mathrm{H}$ diet than for those fed the L diet (Table 3, Figure 2a and $2 \mathrm{~b}$ ). The percentage of concentrate did not affect total VFA concentration, but goats fed the $\mathrm{H}$ diet had lower acetate:propionate ratios and lower proportions of branched-chain VFA (BCVFA, isobutyrate and isovalerate) than goats fed the L diet (Table 3, Figure $2 \mathrm{c}$ and $2 \mathrm{~d}$ ).

The interaction between the percentage of concentrate and the time after feeding had an effect on most of the measurements. The decrease after feeding of the ruminal concentration of BCVFA was more marked for goats fed the $\mathrm{L}$ diet compared with those fed the $\mathrm{H}$ diet (Figure 2d).

The minimal value of $\mathrm{pH}$ after feeding was lower and duration of $\mathrm{pH}$ below 6.0 was higher in goats fed the $\mathrm{H}$ diet compared with those fed the $\mathrm{L}$ diet (Table 3, Figure 2a). Initial value of $\mathrm{pH}$ was much lower at wk 10 than at wk 4 for $\mathrm{H}$ goats $(P<0.001)$. Furthermore, the $\mathrm{pH}$ decrease after feeding was higher in wk 4 than in wk 10 for goats fed the $\mathrm{H}$ diet $(P<0.001)$ but not for goats fed the L diet (Table 3, Figure 2a).

\section{In Sacco Ruminal Degradability and In Vivo Total-Tract Digestibility}

In sacco DM and starch degradability of maize was not affected by the percentage of concentrate (EDDM $=75.9 \pm 0.41 \% ; \mathrm{EDS}=82.6 \pm 0.34 \%)$. The EDDM and EDNDF of grass hay were lower for goats fed the $\mathrm{H}$ diet than for goats fed the L diet (Table 4). Results for in sacco ADF degradability of grass hay were the same as the results of in sacco NDF degradability (EDADF $=19.4 \pm 0.88 \%$ for the $\mathrm{H}$ diet vs. $24.0 \pm 0.88 \%$ for the $\mathrm{L}$ diet; $P=0.001$ ).

The OM total-tract digestibility was higher in goats fed the $\mathrm{H}$ diet $(71.0 \pm 1.31 \%)$ than in those fed the $\mathrm{L}$ 
Table 2. Effect of the percentage of concentrate on BW, intake, milk yield, milk composition, and energy and protein balance

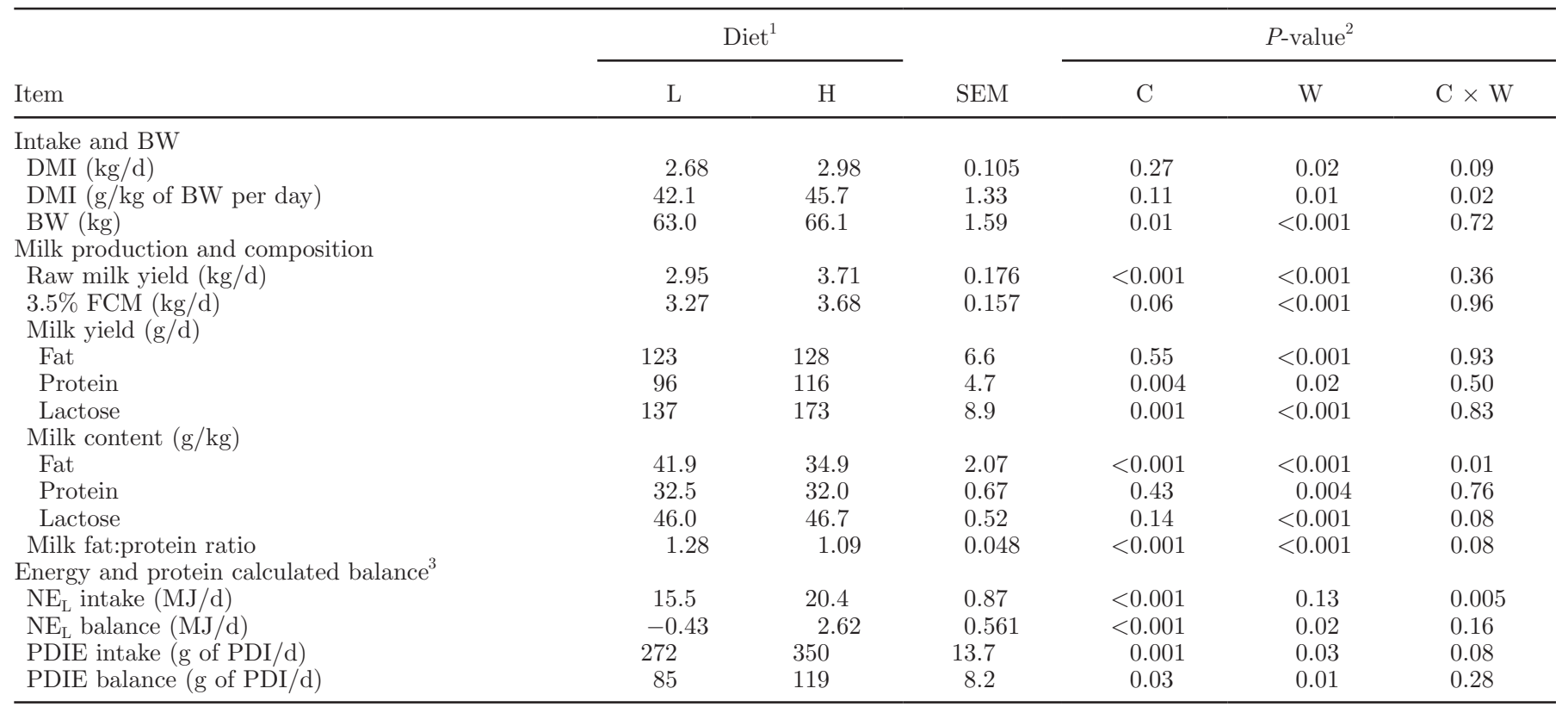

${ }^{1} \mathrm{~L}=$ low percentage of concentrate $(\mathrm{n}=7$ goats), $\mathrm{H}=$ high percentage of concentrate $(\mathrm{n}=6$ goats).

${ }^{2} \mathrm{C}=$ percentage of concentrate; $\mathrm{W}=$ week; $\mathrm{C} \times \mathrm{W}=$ interaction between percentage of concentrate and time.

${ }^{3} \mathrm{PDIE}=$ protein digestible at the level of intestine when energy is limiting.

diet $(65.7 \pm 1.31 \% ; P=0.003)$. Starch digestibility tended to be higher $(98.9 \pm 0.49 \%$ for the $\mathrm{H}$ diet vs. $97.89 \pm 0.49 \%$ for the L diet; $P=0.07$ ), whereas NDF and ADF total-tract digestibility were not affected by experimental diets, with means of $56.8 \pm 1.21 \%$ and $50.7 \pm 1.83 \%$, respectively.

\section{Blood Composition Before and After Feeding}

Plasma concentrations of glucose, insulin, BHBA, urea, and osmotic pressure measured after feeding (Table 5) were not affected by the percentage of concentrate. Plasma concentration of NEFA was lower, whereas L-lactate concentration was higher for goats fed the $\mathrm{H}$ diet than for those fed the $\mathrm{L}$ diet after feeding (Table 5).

Plasma concentrations of insulin, NEFA, BHBA, Llactate, and osmotic pressure measured before feeding were affected by the percentage of concentrate in the same way as after feeding. Goats fed the $\mathrm{H}$ diet had higher plasma concentrations of glucose than those fed the $\mathrm{L}$ diet before feeding (3.28 vs. $3.07 \pm 0.056$ $\mathrm{mmol} / \mathrm{L}$, respectively; $P=0.007)$ and lower plasma concentration of urea-N (18.8 vs. $23.1 \pm 1.08 \mathrm{mmol} / \mathrm{L}$, respectively; $P=0.003$ ). Blood $\mathrm{pH}$ and bicarbonate concentration before feeding were not affected by the percentage of concentrate $(7.41 \pm 0.006$ and $27.5 \pm$ 0.54 , respectively).
Values of NEFA before feeding were higher for goats fed the $\mathrm{L}$ diet compared with goats fed the $\mathrm{H}$ diet (Figure 2e), and the decrease in concentration of NEFA after feeding was higher for goats fed the L diet than for those fed the $\mathrm{H}$ diet (Figure 2e). During the trial, NEFA in plasma before feeding decreased over time for goats fed the L diet, whereas it was quite stable across weeks for goats fed the $\mathrm{H}$ diet (Figure $1 \mathrm{~b}$ ).

\section{Animal Performance and Milk Composition}

Throughout the trial, RMY was higher in goats fed the $\mathrm{H}$ diet than in those fed the $\mathrm{L}$ diet (Table 2, Figure 1a). Compared with goats fed the $\mathrm{L}$ diet, those fed the $\mathrm{H}$ diet had lower MFC and fat:protein ratio, and higher protein and lactose yields (Table 2, Figure 1c). An interaction was observed between the percentage of concentrate and time only on MFC (Table 2), with a higher decrease of MFC for goats fed the L diet compared with the $\mathrm{H}$ diet (Figure 1c). Calculated net energy balance (NEB) and PDI balance were higher for goats fed the $\mathrm{H}$ diet than those fed the $\mathrm{L}$ diet (Table 2 ). The energy balance of goats fed the L diet was negative (Figure $1 \mathrm{~b}$ ).

Compared with goats fed the $\mathrm{L}$ diet, those fed the $\mathrm{H}$ diet had higher proportions of C8:0, C10:0, C12:0, C14:0, cis-12 C18:1, cis-13 C18:1, total trans C18:1 isomers, cis-9,cis-12 C18:2, cis-9,trans-12 and trans- 
a)

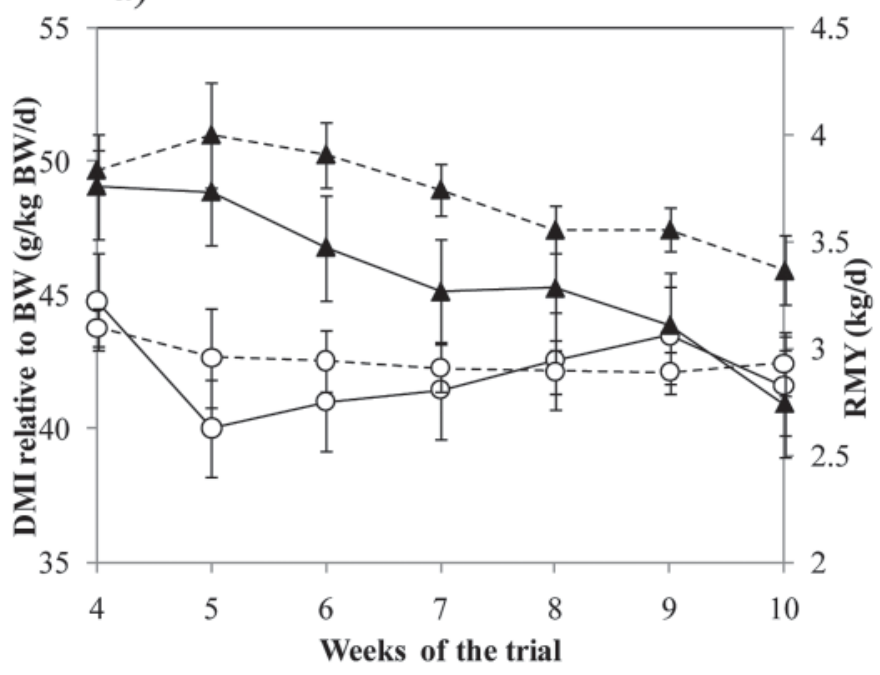

c)

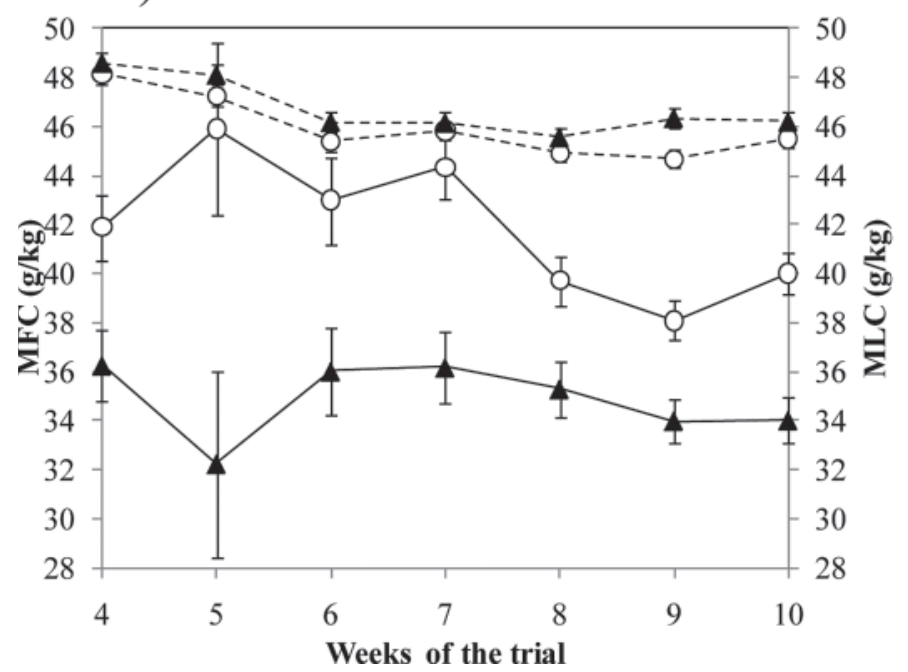

b)

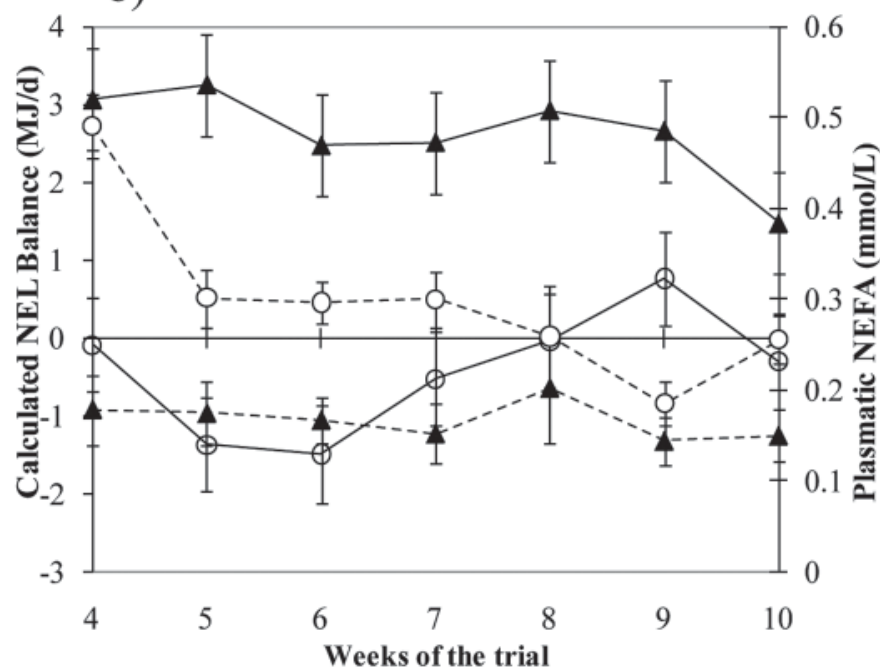

Figure 1. a) DMI relative to BW (-) and raw milk yield (RMY, ----), b) calculated NE balance (-) and plasma concentration of NEFA $(---)$, c) milk fat content $(\mathrm{MFC},--)$ and milk lactose content (MLC, ----) of goats fed experimental TMR with a low (O) or high ( $\mathbf{\Delta})$ percentage of concentrate from wh 4 to 10 .

11,cis-15 C18:2 in milk, and lower proportions of C16:0, C18:0, C20:0, cis-9 C16:1, and cis-9-C18:1 (Table 6). Odd-chain FA and branched-chain FA were not affected by the percentage of concentrate, except for C13:0, iso-C15:0, and iso-C16:0. Ratios cis-9 C14:1/C14:0 to cis-9,trans-11 C18:2/trans-11 C18:1 were not modified by the percentage of concentrate.

\section{DISCUSSION}

\section{Intake, Ruminal Measurements, Nutrient Digestibility, and Plasma Metabolites}

DMI and Physical Measurements of Rumen. In our study, daily DMI was not influenced by the per- centage of concentrate because of high between-goat variability. From a meta-analysis of trials on dairy goats, Sauvant et al. (2007) predicted a mean increase of $100 \mathrm{~g} / \mathrm{d}$ of DMI per $10 \%$ of concentrate when percentage of concentrate of the diet was around $50 \%$. In our trial, the corresponding value was $86 \mathrm{~g} / \mathrm{d}$ per $10 \%$ concentrate.

Considering the cumulative intake profile, 2 periods can be distinguished in our trial. In wk 4, the high percentage of concentrate caused an increase in the rate of intake, due to a lower fill effect of the $\mathrm{H}$ diet compared with the $\mathrm{L}$ diet in accordance with lower NDF and higher starch contents. At wk 10, animals fed the $\mathrm{H}$ diet limited their rate of intake to the same level as 
Table 3. Effect of the percentage of concentrate on rumen measurements at $0,1,2,4$, and $6 \mathrm{~h}$ after the morning feeding in wk 4 and 10

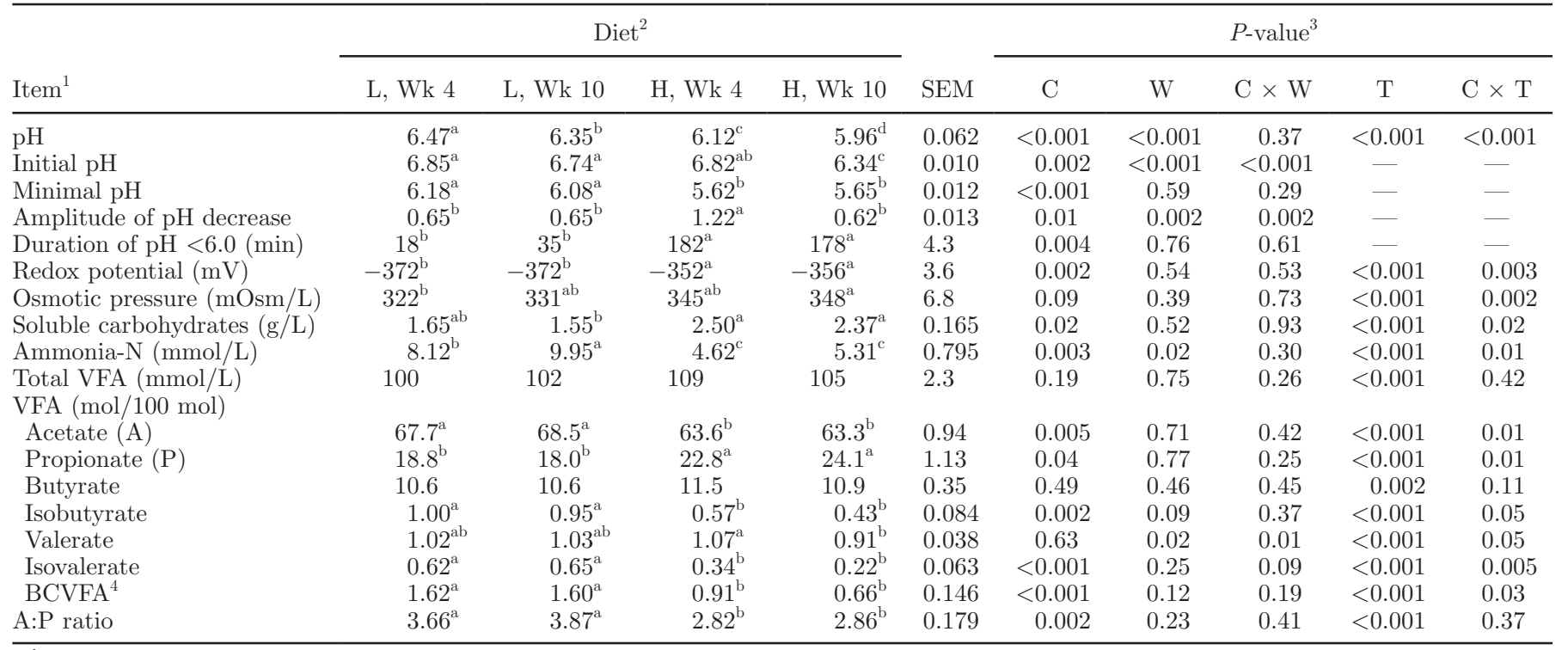

${ }^{\mathrm{a}-\mathrm{d}}$ Within a row, means without a common superscript letter differ $(P<0.05)$.

${ }^{1}$ Data on $\mathrm{pH}$ were calculated after having described $\mathrm{pH}$ data by a third-degree polynomial model as described by Dragomir et al. (2008).

${ }^{2} \mathrm{~L}=$ low percentage of concentrate $(\mathrm{n}=7$ goats), $\mathrm{H}=$ high percentage of concentrate $(\mathrm{n}=6$ goats).

${ }^{3} \mathrm{C}=$ percentage of concentrate; $\mathrm{W}=$ week; $\mathrm{T}=$ time after feeding.

${ }^{4} \mathrm{BCVFA}=$ branched-chain VFA (isobutyrate + isovalerate).

goats fed the L diet and reduced their DMI. Such an adaptation of intake behavior was observed by Desnoyers et al. (2008b) in goats seeking to avoid subacute ruminal acidosis. Abijaoudé et al. (2000b) reported an increase in the number of secondary meals and DMI during these meals when feeding a high percentage of concentrate. These changes of intake behavior would allow greater salivation and thus a higher production of buffer, which could explain the smaller $\mathrm{pH}$ decrease between the onset and the end of the trial for goats fed the $\mathrm{H}$ diet. It is also possible that $\mathrm{H}$ goats had some type of aversion to the high-concentrate diet after suffering subacute ruminal acidosis (Desnoyers et al., 2009). The $\mathrm{H}$ goats reduced their DMI throughout the experiment, resulting in a progressively smaller depression of MFC; however, no significant interaction between the percentage of concentrate and week for RMY and milk lactose contents was observed. However, according to blood $\mathrm{pH}$ and bicarbonate concentration, goats in our study were not in metabolic acidosis.

Rumen $\mathrm{pH}$ in this study was low compared with other published data on dairy goats fed high percentages of concentrate (Cerrillo et al., 1999), but similar to that observed for lactating goats with high levels of DMI/ BW (Santini et al., 1992; Lu, 1993).

Rumen VFA and Consequences on Metabolism. The A:P was comparable to that of lactating goats having a similar level of DMI/BW (Santini et al., 1992). The increase in plasma glucose concentration before feeding the diet with the high percentage of concentrate probably reflects higher hepatic glucogenesis (Bobe et al., 2004), coherent with the higher propionate proportion observed in our trial. Propionate that escapes from gluconeogenesis can be a precursor for the synthesis of the linear odd-chain FA in the mammary gland from propionyl-CoA and malonyl-CoA (MassartLeën et al., 1983). This could explain the increase in the proportion in C13:0 in the milk of goats fed the $\mathrm{H}$ diet compared with those fed the $\mathrm{L}$ diet. However, a large part of the C13:0 also comes from synthesis by rumen bacteria (Vlaeminck et al., 2006).

Ruminal Nitrogen and Metabolism. An increase in nitrogenous concentrate supply generally increases the $\mathrm{NH}_{3}-\mathrm{N}$ content of rumen juice. However, the opposite was found in the current work, as in Abijaoudé et al. (2000a). As the energy availability in the rumen was probably much higher in the $\mathrm{H}$ diet than in the $\mathrm{L}$ diet, rumen microbes of $\mathrm{H}$ diet fed animals would require more $\mathrm{NH}_{3} \mathrm{~N}$ to sustain their growth, which would decrease rumen $\mathrm{NH}_{3}-\mathrm{N}$ concentration, plasma urea, and milk urea. The higher percentage of concentrate decreased the concentrations and the proportions of BCVFA, possibly because of a reduction in catabolism of dietary branched-chain amino acids. The BCVFA (isobutyrate and isovalerate) in the rumen are largely derived from the catabolism of dietary branched-chain amino acids (valine and leucine, respectively; Allison, 1969). As iso-C15:0 and iso-C16:0 are formed from va- 
a

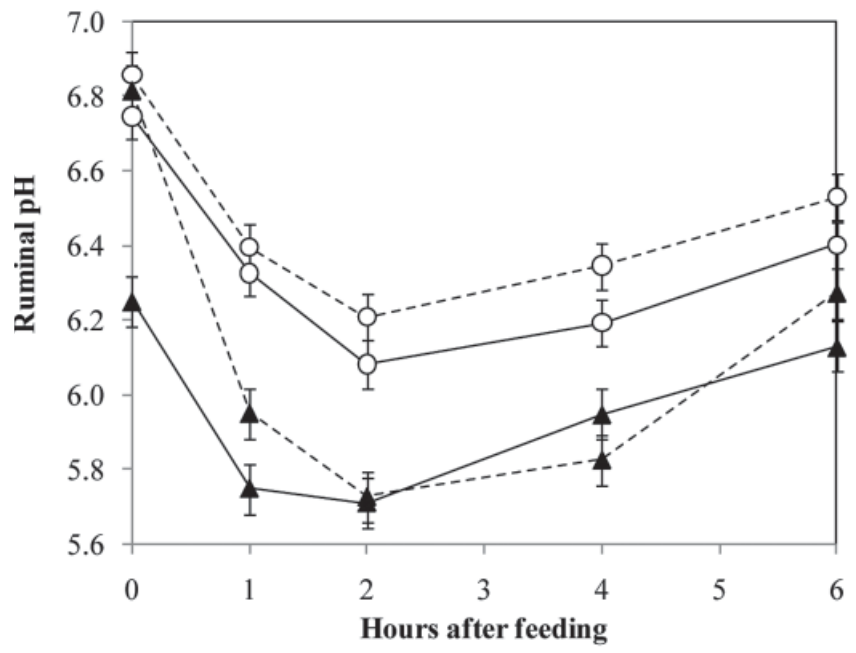

c

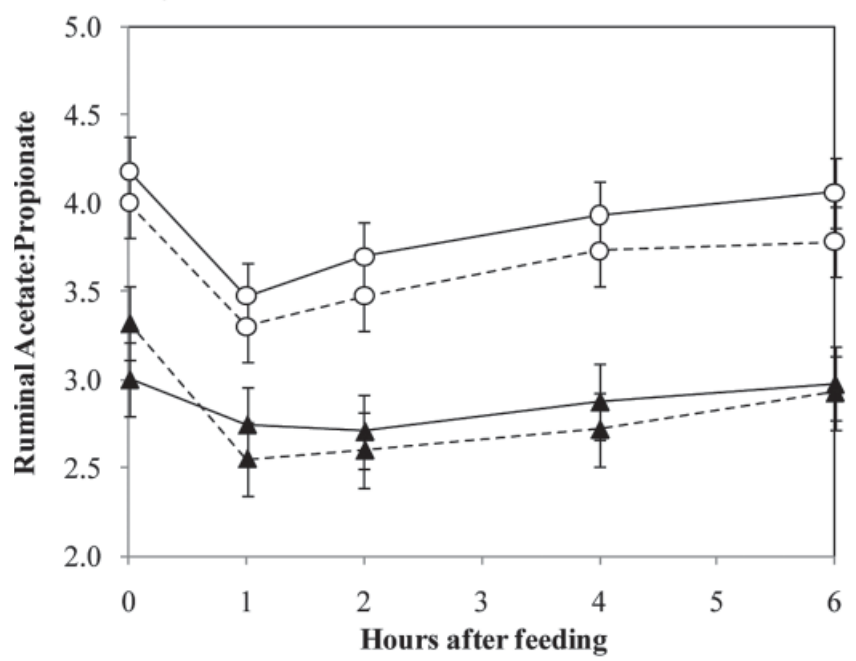

$\mathrm{e}$

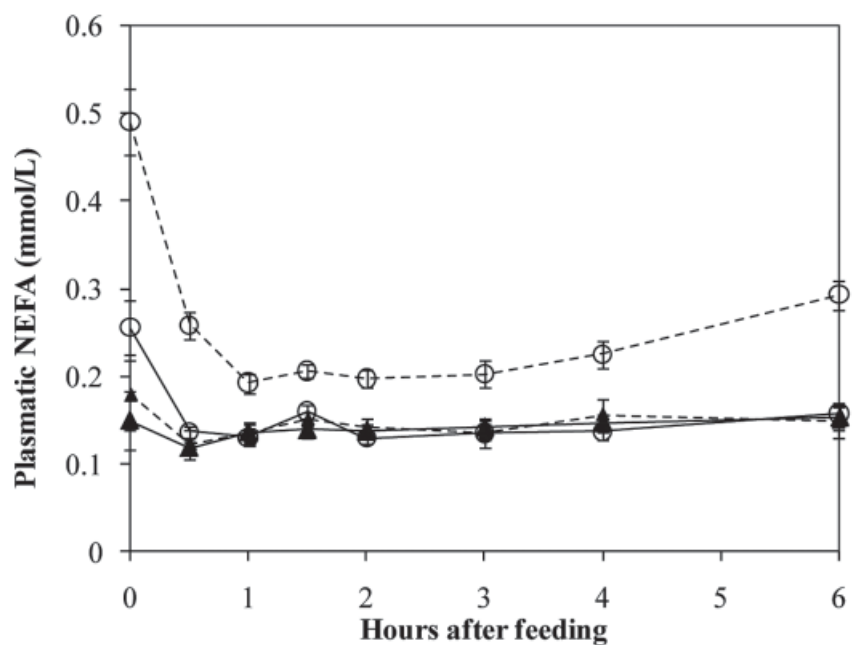

b

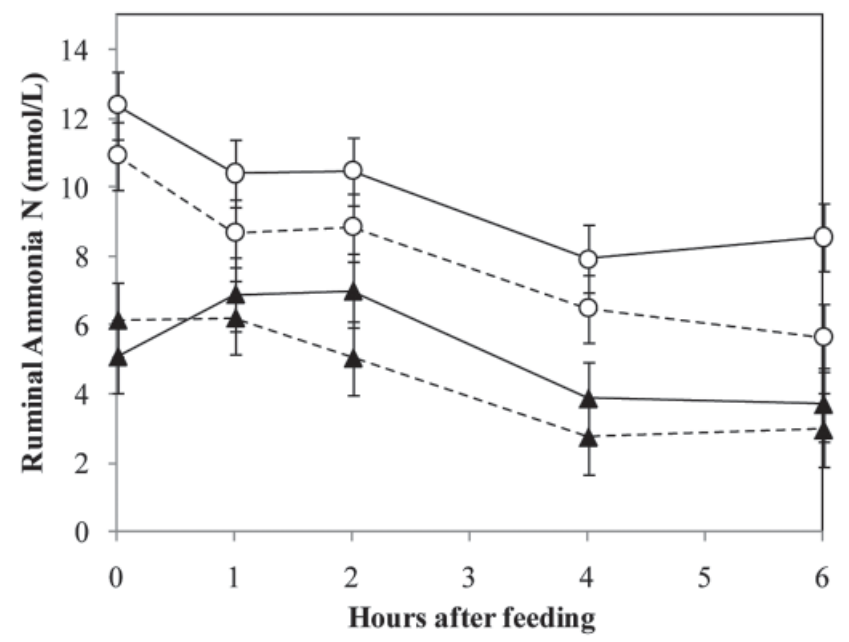

d

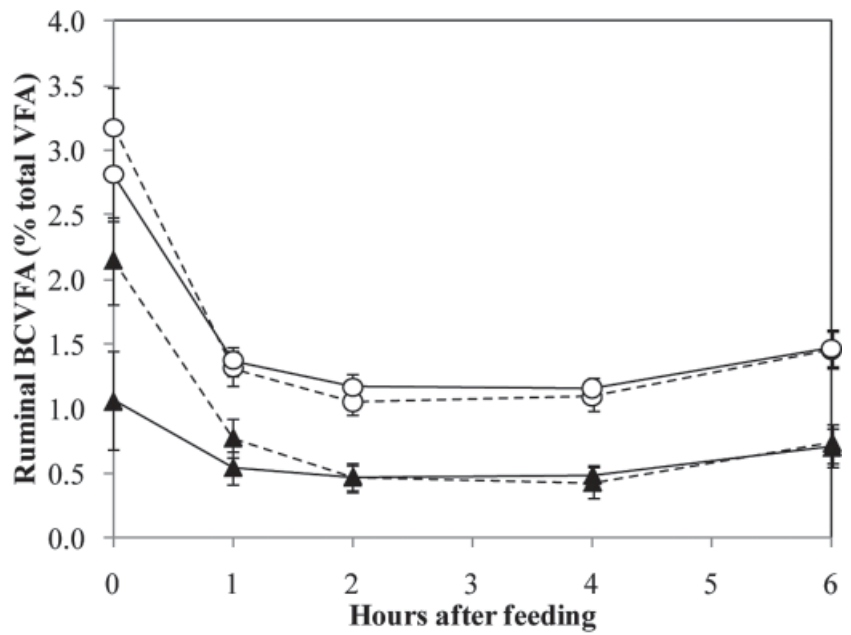

Figure 2. Short-term dynamics of ruminal measurements: a) pH, b) ammonia-N, c) acetate:propionate ratio, d) the proportion of branchedchain VFA, and e) plasma concentrations of NEFA after the morning meal in goats fed experimental TMR with a low $(\bigcirc)$ or high $(\mathbf{\Delta})$ percentage of concentrate in wk 4 (dotted line) and 10 (solid line). 
Table 4. Effect of the percentage of concentrate on in sacco degradability of DM and NDF when grass hay was the tested ingredient

\begin{tabular}{|c|c|c|c|c|}
\hline \multirow[b]{2}{*}{ Item $^{1}$} & \multicolumn{2}{|c|}{$\operatorname{Diet}^{2}$} & \multirow[b]{2}{*}{ SEM } & \multirow{2}{*}{$\frac{P \text {-value }}{\text { Concentrate }}$} \\
\hline & $\mathrm{L}$ & $\mathrm{H}$ & & \\
\hline \multicolumn{5}{|l|}{$\mathrm{DM}$} \\
\hline Soluble: $a$ & 19.0 & 23.7 & 0.86 & $<0.001$ \\
\hline Degradable: $b$ & 51.2 & 46.0 & 1.03 & 0.002 \\
\hline Rate of degradation $(\% / \mathrm{h})$ & 0.065 & 0.045 & 0.0043 & $<0.001$ \\
\hline Effective degradability & 45.2 & 42.8 & 0.50 & 0.001 \\
\hline \multicolumn{5}{|l|}{ NDF } \\
\hline Soluble: $a$ & 1.03 & 4.69 & 1.045 & 0.06 \\
\hline Degradable: $b$ & 59.5 & 64.0 & 3.65 & 0.55 \\
\hline Rate of degradation $(\% / \mathrm{h})$ & 0.059 & 0.041 & 0.0056 & 0.08 \\
\hline Effective degradability & 30.5 & 27.0 & 0.70 & 0.003 \\
\hline
\end{tabular}

${ }^{1}$ Data of DM and NDF disappearance were fitted with the nonlinear model proposed by Ørskov and McDonald (1979): Disappearance $=a+b\left(1-\mathrm{e}^{-c t}\right.$ ), where $a$ is the soluble fraction (\% of total DM or NDF), $b$ the degradable fraction (\% of total DM or NDF), $t$ the time of rumen incubation (h), and $c$ is the relative rate of degradation of fraction $b\left(\mathrm{~h}^{-1}\right)$. Effective degradabilities of DM or NDF were calculated with a particle outflow from the rumen of $0.06 \mathrm{~h}^{-1}$

${ }^{2} \mathrm{~L}=$ low percentage of concentrate ( $\mathrm{n}=6$ goats), $\mathrm{H}=$ high percentage of concentrate $(\mathrm{n}=6$ goats).

line and leucine (Vlaeminck et al., 2006), these iso-FA were also decreased in the rumen and then in the milk.

In Sacco Degradability and In Vivo Digestibility. In sacco degradability of NDF and ADF was lower on the $\mathrm{H}$ diet compared with the $\mathrm{L}$ diet. The depression of fiber digestion can be related to the reduction in activity of the cellulolytic microbes associated with the decrease in ruminal pH (Santini et al., 1992; Archimède et al., 1997). However, total-tract digestibility of NDF and ADF was not modified by the percentage of concentrate, probably because of the partial substitution of ruminal digestion by intestinal digestion (Archimède et al., 1997).

Plasma NEFA and Energy Balance. Despite higher milk energy output for goats fed the $\mathrm{H}$ diet and because of the higher energy content of the $\mathrm{H}$ diet, NEB was improved by $209 \mathrm{kcal}$ per $10 \%$ of concentrate. In the literature, only Rapetti et al. (1997) observed such an NEB increase per $10 \%$ of concentrate. The metaanalysis of Sauvant et al. (2007) suggested a mean NEB increase of only $119 \mathrm{kcal}$ per $10 \%$ of concentrate with similar contents of concentrate. Lower NEB was associated with higher plasma NEFA concentrations of goats fed the L diet. This was expected because plasma NEFA concentration reflects the mobilization of adipose tissue to meet energy requirements (Dunshea et al., 1988).

\section{Milk Production and Milk Composition}

In our study, RMY increased by $229 \mathrm{~g}$ per $10 \%$ of concentrate, whereas Sauvant et al. (2007) predicted a mean RMY increase of $120 \mathrm{~g}$ per $10 \%$ of concentrate for similar contents of concentrate. That meta-analysis compiled articles with a RMY increase between $36 \mathrm{~g}$ (Kawas et al., 1991) and $240 \mathrm{~g}$ (Desnoyers et al., 2008a) per $10 \%$ of concentrate. These differences may be due to the stage of lactation of goats, their energy status, the nature of the diet, and the distribution mode of the diet (TMR vs. forage and concentrate separated).

Table 5. Effect of the percentage of concentrate on plasma composition measured at $0,0.5,1,1.5,2,3,4$, and $6 \mathrm{~h}$ after the morning feeding in wk 4 and 10

\begin{tabular}{|c|c|c|c|c|c|c|c|c|c|c|}
\hline \multirow[b]{2}{*}{ Item } & \multicolumn{4}{|c|}{ Diet $^{1}$} & \multirow[b]{2}{*}{ SEM } & \multicolumn{5}{|c|}{$P$-value ${ }^{2}$} \\
\hline & $\mathrm{L}, \mathrm{Wk} 4$ & $\mathrm{~L}, \mathrm{Wk} 10$ & $\mathrm{H}, \mathrm{Wk} 4$ & $\mathrm{H}, \mathrm{Wk} 10$ & & $\mathrm{C}$ & $\mathrm{W}$ & $\mathrm{C} \times \mathrm{W}$ & $\mathrm{T}$ & $\mathrm{C} \times \mathrm{T}$ \\
\hline Glucose $(\mathrm{mmol} / \mathrm{L})$ & $3.23^{\mathrm{b}}$ & $3.25^{\mathrm{ab}}$ & $3.42^{\mathrm{a}}$ & $3.32^{\mathrm{b}}$ & 0.045 & 0.14 & 0.13 & 0.01 & $<0.001$ & 0.55 \\
\hline NEFA (mmol/L) & $0.259^{\mathrm{a}}$ & $0.156^{\mathrm{b}}$ & $0.146^{\mathrm{b}}$ & $0.141^{\mathrm{b}}$ & 0.0125 & $<0.001$ & $<0.001$ & $<0.001$ & $<0.001$ & $<0.001$ \\
\hline BHBA $(\mathrm{mmol} / \mathrm{L})$ & 0.427 & 0.460 & 0.415 & 0.420 & 0.0246 & 0.57 & 0.50 & 0.61 & $<0.001$ & $<0.001$ \\
\hline Urea $(\mathrm{mmol}$ of $\mathrm{N} / \mathrm{L})$ & $24.1^{\mathrm{a}}$ & $24.2^{\mathrm{a}}$ & $18.1^{\mathrm{b}}$ & $18.8^{\mathrm{ab}}$ & 1.44 & 0.08 & 0.59 & 0.65 & $<0.001$ & 0.55 \\
\hline
\end{tabular}

${ }^{\mathrm{a}-\mathrm{c}}$ Within a row, means without a common superscript letter differ $(P<0.05)$.

${ }^{1} \mathrm{~L}=$ low percentage of concentrate $(\mathrm{n}=7$ goats $), \mathrm{H}=$ high percentage of concentrate $(\mathrm{n}=6$ goats $)$.

${ }^{2} \mathrm{C}=$ percentage of concentrate; $\mathrm{W}=$ week; $\mathrm{T}=$ time after feeding. 
Table 6. Effect of the percentage of concentrate on the fatty acid profile ( $\%$ total fatty acids) of milk fat

\begin{tabular}{|c|c|c|c|c|}
\hline \multirow[b]{2}{*}{ Item } & \multicolumn{2}{|c|}{$\operatorname{Diet}^{1}$} & \multirow[b]{2}{*}{ SEM } & \multirow{2}{*}{$\frac{P \text {-value }}{\text { Concentrate }}$} \\
\hline & $\mathrm{L}$ & $\mathrm{H}$ & & \\
\hline $\mathrm{C}_{4: 0}$ & 1.82 & 1.74 & 0.043 & 0.34 \\
\hline $\mathrm{C}_{6: 0}$ & 2.38 & 2.50 & 0.060 & 0.29 \\
\hline $\mathrm{C}_{8: 0}$ & 2.88 & 3.22 & 0.094 & 0.01 \\
\hline $\mathrm{C}_{10: 0}$ & 9.68 & 11.30 & 0.350 & 0.003 \\
\hline $\mathrm{C}_{11: 0}$ & 0.29 & 0.34 & 0.017 & 0.10 \\
\hline $\mathrm{C}_{12: 0}$ & 3.70 & 4.88 & 0.205 & $<0.001$ \\
\hline $\mathrm{C}_{13: 0}$ & 0.14 & 0.19 & 0.011 & 0.02 \\
\hline $\mathrm{C}_{14: 0}$ & 8.97 & 10.59 & 0.257 & $<0.001$ \\
\hline iso- $\mathrm{C}_{14: 0}$ & 0.10 & 0.10 & 0.007 & 0.99 \\
\hline cis-9 $\mathrm{C}_{14 ! 1}$ & 0.13 & 0.14 & 0.006 & 0.24 \\
\hline $\mathrm{C}_{15: 0}$ & 1.01 & 1.04 & 0.030 & 0.57 \\
\hline iso- $\mathrm{C}_{15: 0}$ & 0.22 & 0.17 & 0.010 & $<0.001$ \\
\hline anteiso- $\mathrm{C}_{15: 0}$ & 0.33 & 0.30 & 0.012 & 0.17 \\
\hline $\mathrm{C}_{16: 0}$ & 27.95 & 23.79 & 0.754 & $<0.001$ \\
\hline iso- $\mathrm{C}_{16: 0}$ & 0.24 & 0.27 & 0.007 & 0.03 \\
\hline cis-9 $\mathrm{C}_{16: 1}$ & 0.48 & 0.37 & 0.027 & 0.05 \\
\hline $\mathrm{C}_{17: 0}$ & 0.70 & 0.71 & 0.009 & 0.78 \\
\hline iso- $\mathrm{C}_{17: 0}$ & 0.47 & 0.42 & 0.047 & 0.65 \\
\hline anteiso- $\mathrm{C}_{17: 0}$ & 0.33 & 0.34 & 0.007 & 0.58 \\
\hline $\mathrm{C}_{18: 0}$ & 9.23 & 8.07 & 0.343 & 0.04 \\
\hline trans- 6 , trans- 7 , and trans- $8 \mathrm{C}_{18: 1}$ & 0.30 & 0.43 & 0.023 & $<0.001$ \\
\hline trans-9 $\mathrm{C}_{18: 1}$ & 0.29 & 0.42 & 0.021 & $<0.001$ \\
\hline trans $-10 \mathrm{C}_{18: 1}$ & 0.38 & 0.67 & 0.047 & $<0.001$ \\
\hline trans $-11 \mathrm{C}_{18: 1}$ & 1.38 & 2.78 & 0.231 & $<0.001$ \\
\hline trans $-12 \mathrm{C}_{18: 1}$ & 0.34 & 0.51 & 0.030 & $<0.001$ \\
\hline cis- 6 and trans-13 and trans- $14 \mathrm{C}_{18: 1}$ & 0.23 & 0.59 & 0.055 & 0.01 \\
\hline trans- $15 \mathrm{C}_{18: 1}$ & 0.29 & 0.33 & 0.011 & 0.01 \\
\hline trans- $16 \mathrm{C}_{18: 1}$ & 0.25 & 0.32 & 0.013 & 0.01 \\
\hline cis-9 $\mathrm{C}_{18: 1}$ & 18.51 & 15.32 & 0.677 & 0.01 \\
\hline cis-11 $\mathrm{C}_{18: 1}$ & 0.41 & 0.46 & 0.015 & 0.10 \\
\hline cis- $12 \mathrm{C}_{18: 1}$ & 0.26 & 0.47 & 0.041 & 0.003 \\
\hline cis-13 $\mathrm{C}_{18: 1}$ & 0.08 & 0.09 & 0.004 & 0.02 \\
\hline cis- 9, cis- $12 \mathrm{C}_{18: 2}$ & 2.81 & 3.35 & 0.116 & 0.004 \\
\hline cis- 9 , trans- $12 \mathrm{C}_{18: 2}$ & 0.05 & 0.06 & 0.001 & 0.01 \\
\hline cis- 9 , trans $-11 \mathrm{C}_{18: 2}$ & 0.65 & 1.28 & 0.112 & $<0.001$ \\
\hline trans- 11 , cis- $15 \mathrm{C}_{18: 2}$ & 0.06 & 0.09 & 0.006 & 0.01 \\
\hline cis- 9 , cis- 12, cis- $15 \mathrm{C}_{18: 3}$ & 0.85 & 0.78 & 0.021 & 0.10 \\
\hline $\mathrm{C}_{20: 0}$ & 0.16 & 0.13 & 0.008 & 0.003 \\
\hline $\mathrm{C}_{20: 4}$ & 0.12 & 0.11 & 0.004 & 0.16 \\
\hline Unidentified fatty acids & 1.18 & 1.28 & 0.085 & 0.16 \\
\hline Saturated fatty acids & 70.61 & 69.76 & 0.673 & 0.46 \\
\hline Sum of trans $\mathrm{C}_{18: 1}+$ cis- $6 \mathrm{C}_{18: 1}$ & 3.43 & 5.96 & 0.420 & $<0.001$ \\
\hline Monounsaturated fatty acids & 23.33 & 22.78 & 0.513 & 0.56 \\
\hline Polyunsaturated fatty acids & 4.82 & 6.03 & 0.194 & 0.001 \\
\hline cis-9 $\mathrm{C}_{14: 1} / \mathrm{C}_{14: 0}$ & 0.01 & 0.01 & 0.001 & 0.54 \\
\hline cis-9 $\mathrm{C}_{16: 1} / \mathrm{C}_{16: 0}$ & 0.02 & 0.02 & 0.001 & 0.58 \\
\hline cis-9 $\mathrm{C}_{18: 1} / \mathrm{C}_{18: 0}$ & 2.05 & 1.92 & 0.091 & 0.37 \\
\hline cis- 9 , trans- $11 \mathrm{C}_{18: 2} /$ trans- $11 \mathrm{C}_{18: 1}$ & 0.47 & 0.46 & 0.013 & 0.72 \\
\hline
\end{tabular}

${ }^{1} \mathrm{~L}=$ low percentage of concentrate $(\mathrm{n}=7$ goats), $\mathrm{H}=$ high percentage of concentrate ( $\mathrm{n}=6$ goats).

Milk protein yield increased with the higher proportion of concentrate in the diet but MPC was not modified, in agreement with the observations of Rapetti et al. (1997). The greater milk synthesis could be related to the higher microbial protein synthesis in the $\mathrm{H}$ diet compared with the L diet.

Feeding high-concentrate diets generally induces low MFC in goats (Sauvant et al., 2007). A decrease of $4.48 \mathrm{~g}$ of fat $/ \mathrm{kg}$ of milk between goats fed the $\mathrm{H}$ diet and those fed the $\mathrm{L}$ diet was predicted from the relationship determined by Schmidely and Sauvant (2001) for goats, whereas in the current study the actual decrease was $6.50 \mathrm{~g}$ of fat $/ \mathrm{kg}$ of milk. Because milk fat yield was not modified by the percentage concentrate, the decrease of MFC can be related mainly to a dilution effect.

Feeding high-concentrate diets does not generally modify or increase the proportion of FA with 4 to 8 carbon atoms in milk (Calderon et al., 1984; Ledoux et al., 2002; Andrade and Schmidely, 2006). In goats fed the $\mathrm{H}$ diet, the proportions of medium-chain FA (FA with 
10 to 16 carbon atoms) in milk increased, except for the proportion of C16:0. Conflicting results have been reported concerning medium-chain FA in dairy goats: C10:0 and C12:0 increased (Andrade and Schmidely, 2006) or were not modified by a higher proportion of concentrate in the diet (Calderon et al., 1984; Ledoux et al., 2002), whereas decreases in C14:0 and C16:0 were also observed by Andrade and Schmidely (2006). Discrepancies between these data and our results may be due to the use of a calcium palm oil salt in the $\mathrm{L}$ diet that is rich in C16:0 and cis-9 C18:1 and to a lesser extent in cis-9,cis-12 C18:2. Indeed, mammary synthesis of medium-chain FA is inhibited by dietary C18:0 and C18:1 (Chilliard et al., 1993; Teh et al., 1994), which may explain the low proportion of FA from C10:0 to C14:0 and the high proportion of C16:0 in milk of goats fed the L diet in our study. The increase in the percentage of concentrate in our study decreased the proportion of C18:0, possibly because of higher dietary amounts of this $\mathrm{FA}$ in the $\mathrm{L}$ diet than in the $\mathrm{H}$ diet, and to ruminal hydrogenation conditions probably more saturating for the FA of the $\mathrm{L}$ diet than those of the $\mathrm{H}$ diet (see below). The proportions of cis-9 C16:1 and cis-9 C18:1 in milk decreased with increasing percentage of concentrate. These FA partly originate from their plasma uptake and partly from desaturation of C16:0 and C18:0 by mammary $\Delta^{9}$-desaturase (Chilliard and Ferlay, 2004). The decrease in the proportions of cis-9 C16:1 and cis-9 C18:1 was directly linked to the decrease of the proportions of $\mathrm{C} 16: 0$ and $\mathrm{C} 18: 0$, because the calculated proxy of $\Delta^{9}$-desaturase activity (cis-9 C18:1/C18:0) was not modified by the concentrate proportion. The proportions of total trans-C18:1 were increased by the percentage of concentrate as already observed in the literature (Calderon et al., 1984; Ledoux et al., 2002; Andrade and Schmidely, 2006). These isomers are intermediary products of ruminal biohydrogenation of the dietary polyunsaturated FA (Glasser et al., 2008). Consequently, ruminal biohydrogenation conditions in goats fed the $\mathrm{H}$ diet appear to stay high but would be slightly less efficient than for goats fed the L diet. These differences probably arise from changes in rumen microbial populations (Kaufmann et al., 1980) associated with the lower ruminal $\mathrm{pH}$ on the $\mathrm{H}$ diet. In this context, cellulolytic bacteria seem to be the most active in the ruminal biohydrogenation process (Harfoot and Hazlewood, 1997). Despite the increase of trans-C18:1 isomers with the $\mathrm{H}$ diet, no modification of the proportion in total trans-C18:1 was noticed in our study, and notably no shift from trans-11 C18:1 to trans-10 C18:1 was observed. Further, the isomer trans-10,cis-12 C18:2 was not detected. Relative to cows, goats are less likely to produce trans-10 $\mathrm{C} 18: 1$ and trans-10,cis-12 C18:2. They are also less sensitive to the antilipogenic activ- ity of trans-10,cis-12 C18:2 (Shingfield et al., 2010). The trans-11 C18:1 is the major trans C18:1 isomer, which explains why cis-9,trans-11 C18:2 was the major conjugated linoleic acid, due to the action of the $\Delta^{9}$ desaturase of mammary gland.

\section{CONCLUSIONS}

This study evaluated the effect of high-concentrate diets on dairy goats. The results were consistent with previous reports in goats and dairy cows. This work extended the current information by collecting a large number of simultaneous measurements for a relatively long time. Such a study is essential to generate data for building or improving empirical and mechanistic models aimed at predicting the response to dietary change at the digestive, metabolic, and mammary levels.

\section{ACKNOWLEDGMENTS}

J. Teissier, A. Eymard, G. Durandet, J.-P. Bonte, J. Chevallier, A. Severin and J.-L. Le Pierres (INRA, UMR791 Modélisation Systémique Appliquée aux Ruminants, Paris and Thiverval-Grignon, France) are gratefully acknowledged for obtaining research data on goats. We thank O. Dhumez, F. Ternois, H. Albarello and L. Péricard (INRA, UMR791 Modélisation Systémique Appliquée aux Ruminants, Paris, France) for the analysis of the samples.

\section{REFERENCES}

Abijaoudé, J. A., P. Morand-Fehr, J. Tessier, P. Schmidely, and D. Sauvant. 2000a. Influence of forage:concentrate ratio and type of starch in the diet on feeding behaviour, dietary preferences, digestion, metabolism and performance of dairy goats in mid lactation. Anim. Sci. 71:359-368.

Abijaoudé, J. A., P. Morand-Fehr, J. Tessier, P. Schmidely, and D. Sauvant. 2000b. Diet effect on the daily feeding behaviour, frequency and characteristics of meals in dairy goats. Livest. Prod. Sci. 64:29-37.

AFNOR. 1997. V18-121. Aliments des animaux. Détermination enzymatique de la teneur totale en amidon. Association française de normalisation (AFNOR), La Plaine Saint-Denis, France.

Allison, M. J. 1969. Biosynthesis of amino acids by ruminal microorganisms. J. Anim. Sci. 29:797-807.

Andrade, P. V. D., and P. Schmidely. 2006. Influence of percentage of concentrate in combination with rolled canola seeds on performance, rumen fermentation and milk fatty acid composition in dairy goats. Livest. Sci. 104:77-90.

Archimède, H., D. Sauvant, J. Hervieu, F. Ternois, and C. Poncet. 1996. Effects of the nature of roughage and concentrate and their proportion on ruminal characteristics of non lactating goats, consequences on digestive interactions. Anim. Feed Sci. Technol. $58: 267-282$.

Archimède, H., D. Sauvant, and P. Schmidely. 1997. Quantitative review of ruminal and total tract digestion of mixed diet organic matter and carbohydrates. Reprod. Nutr. Dev. 37:173-189.

Barnouin, J., N. El Idilbi, Y. Chilliard, J. P. Chacornac, and R. Lefaivre. 1986. Micro-dosage automatisé sans déprotéinisation du $\beta$-hydroxybutyrate plasmatique chez les bovins. Ann. Rech. Vet. $17: 129-139$. 
Baumont, R. 1988. Cinétique d'ingestion lors du grand repas chez le mouton: Influence du temps d'accès au foin et de son ingestibilité. Reprod. Nutr. Dev. 28:183-184.

Baumont, R., J. P. Dulphy, D. Sauvant, G. Tran, F. Meschy, J. L. Peyraud, and P. Champciaux. 2007. Les tables de la valeur des aliments. Pages 181-286 in Alimentation des bovins, ovins et caprins. Besoins des animaux-Valeurs des Aliments. Tables INRA 2007. Ed. Quae, Versailles, France.

Bobe, G., J. W. Young, and D. C. Beitz. 2004. Pathology, etiology, prevention, and treatment of fatty liver in dairy cows. J. Dairy Sci. 87:3105-3124.

Brown, M. E., and M. S. Boston. 1961. Ultra-microsinger determination using 2.9 dimethyl. 1. 10 phenanthroline hydrochloryde (neocuproine). Diabetes 10:60-62.

Calderon, I., E. J. De Peters, N. E. Smith, and A. A. Franke. 1984. Composition of goat's milk: Changes within milking and effects of a high concentrate diet. J. Dairy Sci. 67:1905-1911.

Cerrillo, M. A., J. R. Russell, and M. H. Crump. 1999. The effects of hay maturity and forage to concentrate ratio on digestion kinetics in goats. Small Rumin. Res. 32:51-60.

Chilliard, Y., M. Doreau, G. Gagliostro, and Y. Elmeddah. 1993. Addition de lipides protégés (encapsulés ou savons de calcium) à la ration de vaches laitières. Effets sur les performances et la composition du lait. INRA. Prod. Anim. 6:139-150.

Chilliard, Y., and A. Ferlay. 2004. Dietary lipids and forages interactions on cow and goat milk fatty acid composition and sensory properties. Reprod. Nutr. Dev. 44:467-492.

Desnoyers, M., C. Duvaux-Ponter, K. Rigalma, S. Roussel, O. Martin, and S. Giger-Reverdin. 2008a. Effect of concentrate percentage on ruminal $\mathrm{pH}$ and time-budget in dairy goats. Animal 2:1802-1808.

Desnoyers, M., S. Giger-Reverdin, C. Duvaux-Ponter, and D. Sauvant. 2009. Modeling of off-feed periods caused by subacute acidosis in intensive lactating ruminants: Application to goats. J. Dairy Sci. 92:3894-3906.

Desnoyers, M., S. Giger-Reverdin, C. Duvaux-Ponter, E. Lebarbier, and D. Sauvant. 2008b. Modélisation des épisodes d'acidose subclinique et du comportement alimentaire associé: application à la chèvre laitière. Renc. Rech. Rumin. 15:339-343.

Dragomir, C., D. Sauvant, J. L. Peyraud, S. Giger-Reverdin, and B Michalet-Doreau. 2008. Meta-analysis of 0 to $8 \mathrm{~h}$ post-prandial evolution of ruminal $\mathrm{pH}$. Animal 2:1437-1448.

Dunshea, F. R., A. W. Bell, and T. E. Trigg. 1988. Relations between plasma non-esterified fatty acid metabolism and body tissue mobilization during chronic undernutrition in goats. Br. J. Nutr. 60:633-644.

FAO. 2010. FAOSTAT. Accessed April 14, 2010. http://faostat.fao. org/site/569/DesktopDefault.aspx.

Giger, S., P. Thivend, D. Sauvant, M. Dorléans, and P. Journaix. 1987. Etude de l'influence préalable de différents traitements amylolytiques sur la teneur en résidu NDF d'aliments du bétail. Ann. Zootech. 36:39-48.

Glasser, F., P. Schmidely, D. Sauvant, and M. Doreau. 2008. Digestion of fatty acids in ruminants: A meta-analysis of flows and variation factors: 2. C18 fatty acids. Animal 2:691-704.

Harfoot, C. G., and G. P. Hazlewood. 1997. Lipid metabolism in the rumen. Pages $382-426$ in The rumen microbial ecosystem. P. N. Hobson, and C. S. Stewart, ed. Blackie Academic \& Professional, London, UK.

Huhtanen, P., M. Rinne, and J. Nousiainen. 2009. A meta-analysis of feed digestion in dairy cows. 2. The effects of feeding level and diet composition on digestibility. J. Dairy Sci. 92:5031-5042.

ISO. 1978. ISO 5984. Animal Feedingstuffs. Determination of Crude Ash. International Organisation for Standardisation, Geneva, Switzerland.

Kaufmann, W., H. Hagemeister, and G. Dirksen. 1980. Adaptation to changes in dietary composition, level and frequency of feeding. Pages 587-602 in Digestive Physiology and Metabolism in Ruminants. Y. Ruckebusch and P. Thivend, ed. MTP Press Ltd., Lancaster, UK.
Kawas, J. R., J. Lopes, D. L. Danelon, and C. D. Lu. 1991. Influence of forage-to-concentrate ratios on intake, digestibility, chewing and milk production of dairy goats. Small Rumin. Res. 4:11-18.

Khorasani, G. R., and J. J. Kennelly. 2001. Influence of carbohydrate source and buffer on rumen fermentation characteristics, milk yield, and milk composition in late-lactation Holstein cows. J. Dairy Sci. 84:1707-1716.

Kristensen, N. B. 2000. Quantification of whole blood short-chain fatty acids by gas chromatographic determination of plasma 2-chloroethyl derivatives and correction for dilution space in erythrocytes. Acta Agric. Scand. A Anim. Sci. 50:231-236.

Lechartier, C., and J. L. Peyraud. 2010. The effects of forage proportion and rapidly degradable dry matter from concentrate on ruminal digestion in dairy cows fed corn silage-based diets with fixed neutral detergent fiber and starch contents. J. Dairy Sci 93:666-681.

Ledoux, M., A. Rouzeau, P. Bas, and D. Sauvant. 2002. Occurrence of trans-C18:1 fatty acid isomers in goat milk: Effect of two dietary regimens. J. Dairy Sci. 85:190-197.

Lu, C. D. 1993. Implication of feeding isoenergetic diets containing animal fat on milk composition of alpine does during early lactation. J. Dairy Sci. 76:1137-1147.

Massart-Leën, A. M., E. Roets, G. Peeters, and R. Verbeke. 1983. Propionate for fatty acid synthesis by the mammary gland of the lactating goat. J. Dairy Sci. 66:1445-1454.

Morand-Fehr, P., V. Fedele, M. Decandia, and Y. Le Frileux. 2007. Influence of farming and feeding systems on composition and quality of goat and sheep milk. Small Rumin. Res. 68:20-34.

Nousiainen, J., M. Rinne, and P. Huhtanen. 2009. A meta-analysis of feed digestion in dairy cows. 1. The effects of forage and concentrate factors on total diet digestibility. J. Dairy Sci. 92:5019-5030.

Ørskov, E. R., and I. McDonald. 1979. The estimation of protein degradability in the rumen from incubation measurements weighted according to rate of passage. J. Agric. Sci. (Camb.) 92:499-503.

Rapetti, L., A. Tamburini, G. M. Crovetto, G. Galassi, and G. Succi. 1997. Energy utilization of diets with different hay proportions in lactating goats. Zootec. Nutr. Anim. 23:317-328.

Santini, F. J., C. D. Lu, M. J. Potchoiba, J. M. Fernandez, and S. W. Coleman. 1992. Dietary fiber and milk yield, mastication, digestion, and rate of passage in goats fed alfalfa hay. J. Dairy Sci. $75: 209-219$.

SAS Institute. 2000. User's Guide. Release 11.04. SAS Institute Inc. Cary, NC.

Sauvant, D., S. Giger-Reverdin, and F. Meschy. 2007. Alimentation des caprins. Pages 137-148 in Alimentation des bovins, ovins et caprins. Besoins des animaux-Valeurs des Aliments. Tables INRA 2007. Ed. Quae, Versailles, France.

Schmidely, P., and D. Sauvant. 2001. Taux Butyreux et composition de la matière grasse du lait chez les petits ruminants: Effets de l'apport de matières grasses ou d'aliments concentrés. INRA. Prod. Anim. 14:333-352.

Shingfield, K. J., L. Bernard, C. Leroux, and Y. Chilliard. 2010. Role of trans fatty acids in the nutritional regulation of mammary lipogenesis in ruminants. Animal 4:1140-1166.

Sweeney, R. A., and P. R. Rexroad. 1987. Comparison of Leco FP228 'nitrogen determinator' with AOAC copper catalyst Kjeldahl method for crude protein. J. AOAC Int. 70:1028-1030.

Teh, T. H., L. T. Trung, Z. H. Jia, T. A. Gipson, K. B. Ogden, and T. F. Sweeney. 1994. Varying amount of rumen-inert fat for high producing goats in early lactation. J. Dairy Sci. 77:253-258.

Van Soest, P. J., and R. H. Wine. 1967. Use of detergents in the analysis of fibrous feeds. IV. Determination of plant cell-wall constituents. J. AOAC 50:50-55.

Vérité, R., B. Michalet-Doreau, P. Chapoutot, J. L. Peyraud, and C. Poncet. 1987. Révision du système des Protéines Digestibles dans l'Intestin (PDI). Bull. Tech. CRZV Theix 70:19-34.

Vlaeminck, B., V. Fievez, A. R. J. Cabrita, A. J. M. Fonseca, and R. J. Dewhurst. 2006. Factors affecting odd- and branched-chain fatty acids in milk: A review. Anim. Feed Sci. Technol. 131:389-417.

Weatherburn, M. W. 1967. Phenol-hypochlorite reaction for determination of ammonia. Anal. Chem. 38:971-977. 